\title{
Al-Madãris
}

VOL. 2, NO. 2, 2021

E-ISSN: 2745-9950

https://journal.staijamitar.ac.id/index.php/almadaris

\section{STUDI KOMPARASI PEMIKIRAN ULAMA BADIUZZAMAN SAID NURSI DAN KITAB TA'LIM MUTA'ALIM TERHADAP PENDIDIKAN AKHLAK GENERASI MUDA}

\author{
Naela Maghfiroh \\ Institut Agama Islam Negeri (IAIN) Salatiga \\ naylamafi2204@gmail.com
}

Abstract

This research is motivated by the impact of moral education of the younger generation which is starting to become the public spotlight due to abandoning moral values. So the writer is interested in studying the concept of moral education according to the cleric Badiuzzaman Said Nursi and the Book byTa'lim Muta'alim by the scholar Sheikh al-Zarnuzi. This study uses the type of literature study research. The approach used in this research is a historical approach. The method used to analyze the content is (content analysis). The purpose of this study is to find out how the concept of moral education according to the cleric Badiuzzaman Said Nursi and Kitab Ta'lim Muta'alim, and to find out the comparison of the concept of thought according to the cleric Badiuzzaman Said Nursi and the Kitab Ta'lim Muta'alim to the moral education of the younger generation.

Keywords: Moral education concept, Badiuzzaman Said Nursi, Ta'lim Muta'alim's book

\section{A. Pendahuluan}

Pendidikan merupakan hal yang terpenting dalam menjalani kehidupan. Hal tersebut tergambar ketika Rasulullah saw mendapatkan wahyu pertama ialah untuk membaca. Makna dari membaca itu sendiri bukan hanya membaca buku, namun dapat diartikan belajar, belajar disini juga tidak hanya berarti belajar namun juga diamalkan.

Belajar pada hakikatnya ialah memahami alam sekitar dan/atau wahyu Allah swt baik itu tersirat maupun tersurat. Jika dilihat dari fenomena yang terjadi pada 
era sekarang ini, banyak kesenjangan yang terjadi pada pendidikan moral/akhlak. Contohnya ketika para orang tua lebih menekankan prestasi anak di sekolah daripada bagaimana anak dapat berperilaku baik pada kesehariannya. Melihat fenomena ini, pendidikan berbasis akhlak perlu ditegaskan kembali, karena faktanya di Indonesia sekarang banyak orang yang pandai dalam keilmuan namun sedikit orang yang berakhlak. Imam al-Ghazali dalam kitabnya yang berjudul Ihya Ulumudin membagi manusia ke dalam empat macam yakni sebagai berikut.

1. Orang yang tahu dan tahu bahwa dirinya tahu

2. Orang yang tahu tetapi tidak tahu bahwa dirinya tahu

3. Orang yang tidak tahu tetapi tahu bahwa dirinya tahu

4. Orang yang tidak tahu dan tidak tahu bahwa dirinya tidak tahu

Imam Al-Ghazali membagi ke dalam empat kategori manusia berdasarkan bagaimana seseorang dapat menggunakan atau menerapkan ilmu tersebut dalam kehidupannya.

Negara kita memang memerlukan orang yang berpendidikan tinggi, karena dalam kancah dunia secara global dan zaman yang semakin maju maka tentunya negara harus memiliki sumber daya manusia yang unggul agar dapat bersaing dengan negara lain. Namun perlu digaris bawahi, bahwa alangkah lebih baiknya ialah apabila pendidikan di negara kita lebih menekankan pada pendidikan akhlak sehingga tak hanya cerdas dalam pikiran namun juga cerdas dalam sikap. Kita dapat menggambarkan bagaimana kekacauan pemerintah bangsa ini dan bagaimana pentingnya pendidikan akhlak untuk para generasi penerus bangsa.

Bila dicermati, pada era modernisasi sekarang ini, yang notabennya teknologi semakin pesat dan gaya hidup yang tidak mencerminkan perilaku terpuji sudah marak tak terkendali seharusnya pendidikan akhlak memang harus lebih ditekankan kembali. Masalah seperti ini bukan hanya menjadi tanggung jawab guru agama yang memang tugasnya mengajarkan tentang pendidikan akhlak tetapi semua pihak juga harus membantu dalam pembentukan akhlak yang baik. Baik itu di dalam sekolah maupun luar sekolah (dalam bingkai pendidikan formal maupun nonfomal).

Akhlak merupakan dasar hidup manusia, sehingga manusia dapat menjaga hidupnya. Maka dari itu, kualitas diri seseorang dinilai dari akhlaknya, baik itu urusan hablumminallah maupun hablumminannas. Pendidikan akhlak dimulai dari lingkungan anak sedari kacil, yaitu melalui keluarga. Dengan adanya keluarga dan lingkungan anak tersebut tinggal dapat menjadikan pondasi seorang generasi bangsa dimulai. Salah satu kesalahan yang mungkin tidak di sadari oleh orang tua adalah menyerahkan sepenuhnya pendidikan anaknya ke sekolah atau asrama dari kecil. Hal ini seharusnya menjadi perhatian umum, karena seharusnya anak yang masih kecil perlu membentuk karakternya oleh keluarganya khususnya orangtuanya sendiri. Sebab pendidikan yang berlangsung dalam keluarga bersifat asasi. Dimana orang tua merupakan pendidik pertama, utrama, dan kodrati. Merekalah yang banyak memberika pengaruh dan warna kepribadian seorang anak (Hasbullah, 2009:22).

Sebagai agama yang sempurna, nilai-nilai akhlak yang diajarkan sesuai dengan syari'at Islam. Nilai-nilai akhlak yang diamalkan tentunya akan mendapat

$\overline{\text { Al-Madãris, Volume 2 (2), } 2021}$ 
kebahagiaan baik itu dunia maupun akhirat. Betapa pentingnya akhlak dalam Islam, hingga banyak disebutkan dalam ayat-ayat al-Qur'an dan hadits-hadits Nabi saw. Salah satunya adalah ayat berikut ini:

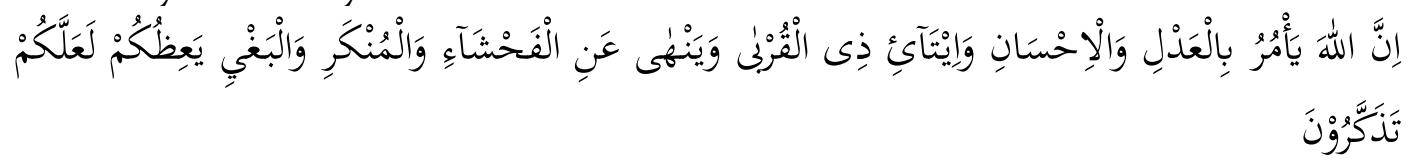

Artinya: Sesungguhnya Allah Menyuruh (kamu) berlaku adil dan berbuat kebajikan, memberi kepada kaum kerabat, dan Allah melarang dari perbuatan keji, kemungkaran dan permusuhan. Dia memberi pengajaran kepadamu agar kamu dapat mengambil pelajaran. (2S. An-Nahl [16]:90)

Ayat di atas dengan jelas menjelaskan tentang pentingnya pendidikan akhlak. Akhlak yang mulia dan mendorong manusia untuk berbuat baik kepada manusia dalam pergaulan sehari-hari.

Di dalam Al-Qur'an ada banyak sekali Keutamaan-keutamaan yang berkaitan dengan akhlak. Para Ulama mengkalkulasikan sebanyak seratus tujuh belas keutamaan (fadilah). Keutamaan tersebut ialah: kejujuran, kesabaran, keadilan, ihsan, berbuat baik, senang membantu orang, pemaaf, pentang mundur, bersih diri, memelihara anak yatim, memenuhi janji, bersikap tawadhu'. Satria dan sebagainya. Menerapkan sifat itu dengan kualitas yang baik merupakan akhlak muslim yang mulia. Dan menjadi manusia sempurna pastilah idaman setiap orang maka dari itu modal yang terpenting adalah akhlak. Hal ini sejalan dengan Noerhidayatullah dalam bukunya "Insan Kamil" yang mengatakan bahwa bekal untuk menjadi manusia sempurna adalah akhlak mulia dan amal saleh.

Bahkan seperti yang kita tahu, Rasul diutus kepada umat manusia untuk memperbaiki akhlak dan menyampaikan risalah-Nya. Seperti dalam hadits Nabi saw "Innama bu'istu li utammima markim al-akhlak" (Sesungguhnya aku diutus di muka bumi ini untuk menyempurnakan akhlak). Dan tidak khayal jika faktor keberhasilan dakwah beliau antara lain karena dukungan akhlaknya.

Dapat disimpulkan bahwa pendidikan akhlak adalah hal yang sangat penting bagi kehidupan manusia, karena didalamnya terdapat pembentukan kepribadian seseorang yang dapat menimbulkan sikap atau tingkah laku yang baik.Disini penulis akan membahas tentang konsep pendidikan akhlak generasi muda menurut Ulama Besar Turki yakni Badiuzzaman Said Nursi yang populer dengan kitab karangannya yakni "Risalah An-Nur" dan kitab yang begitu terkenal yaitu Kitab Ta'lim Muta'alim karangan Syekh Burhanudin Al-Zarnuji.

Konsep pendidikan akhlak yang di miliki oleh Ulama Badiuzzaman Said Nursi memiliki beberapa perbedaan yang mungkin bisa dijadika rujukan sebagai salah satu langkah untuk memberikan perubahan bagi pendidikan akhlak di negara ini khususnya untuk generasi muda. Selain iru, konsep pendidikan akhlak yang yang ditawarkan oleh Burhanuddin Al-Zarnuji patut mendapatkan sorotan secara khusus karena di dalam kitabnya yakni Kitab Ta'lim Muta'alim itu sendiri dapat menajdi

$\overline{\text { Al-Madãris, Volume 2 (2), } 2021}$ 
dasar dalam konsep pendidikan akhlak anatara murid, guru, dan semua orang yang berada dalam lingkup pendidikan.

Berdasarkan paparan diatas, penulis tertarik untuk mengkaji bagaimana konsep pendidikan akhlak menurut Ulama Besar Turki Badiuzzaman Said Nursi dan Kitab Ta'lim Muta'alim karya Syekh Burhanuddin Al-Zarnuji. Dengan cara membandingkan keduanya, sehingga nantinya dapat memunculkan suatu konsep pendidikan akhlak yang dapat membentuk akhlak seseorang menjadi lebih baik. Yang akhirnya dapat memecahkan masalah-masalah moral yang terjadi di negara kita saat ini. Oleh karena itu, penulis mengangkat judul penelitian "Studi Komparasi Pemikiran Ulama Badiuzzaman Said Nursi Dan Kitab Ta'lim Muta'alim Terhadap Pendidikan Akhlak Generasi Muda"

\section{B. Review Literatur}

Dalam Bahasa Arab istilah pendidikan digunakan untuk berbagai pengertian, antara lain tarbiyah, tahzib, ta'lim, ta'dib, siyasat, mawa'izh, 'ada ta'awwud dan tadrib. Sedangkan untuk istilah tarbiyah, tahzib dan ta'dib sering diartikan pendidikan. Ta'lim diartikan pengajaran, siyasat diartikan siasat, pemerintahan, politik atau pengaturan. Muwa'izh diartikan pengajaran atau peringan. 'Ada ta'awudz diartikan pembiasaan dan tadrib diartikan pelatihan.

Diantara mereka yang menjadikan istilah-istilah diatas untuk tujuan pendidikan yakni Ibn Maskawaih dalam bukunya Tahzibul Akhlak, Ibnu Sina memberi judul salah satu bukunya Kitab Al-Siyasat, Ibnu Al-jazzar Al-Qairawani membuat judul salah satu bukunya berjudul siyasat al-shibyan wa tadribuhum, dan Burhan al-Islam Al-Zarnuji memberikan judul salah satu karyanya Ta'lim al-Muta'alim tharik at-ta'alum. Walau terjadi berbagai perbedaan, namun para ahli tidak mempersoalkan penggunaan istilah diatas. Karena, pada dasarnya semua pandangan yang berbeda itu bertemu dalam suatu kesimpulan awal, bahwa pendidikan merupakan suatu proses penyiapan generasi muda untuk menjalankan kehidupan dan memenuhi tujuan hidupnya secara lebih baik.

Secara fakta istilah "pendidikan" telah menempati banyak tempat dan didefinisikan secara berbeda-beda oleh berbagai pakar, yang banyak dipengaruhi pendangan dunia masing-masing. Para pakar sependapat bahwa pendidikan lebih daripada sekadar pengajaran. Kalau pengajaran dapat dikatakan sebagai "suatu proses transfer ilmu belaka", namun pendidikan merupakan "transformasi nilai dan pembentukan kepribadian dengan segala aspek yang dicakupnya". Dengan demikian, pengajaran lebih berorientasi pada pembentukan "tukang-tukang" atau para spesialis yang terkurung dalam ruang spesialisasinya sempit, karena itu, perhatian dan minatnya lebih bersifat teknis. Artinya, perbedaan pendidikan dengan pengajaran terletak pada "penekanan anak didik di samping transfer ilmu dan keahlian".

Al-Attas mendefinisikan pendidikan adalah suatu proses penanaman sesuatu ke dalam diri manusia. Suatu proses "penanaman" mengacu pada metode dan sistem untuk menanamkan apay yang disebut sebagai "pendidikan" secara bertahap "sesuatu"

$\overline{\text { Al-Madãris, Volume 2 (2), } 2021}$ 
mengacu pada kandungan yang ditanamkan; dan "diri manusia" mengacu pada penerima proses dan kandungan itu.

Sedangkan kata "akhlak" dalam Bahasa Indonesia dapat di setarakan dengan kata moral, etika, watak, budi pekerti, tingkah laku, perangai dan kesusilaan. Akhlak jamak dari Khuluq yang berarti adat kebiasaan (al-'adat), perangi, tabi'at (at-jiyyat), watak (at-thab), adab atau sopan santun (al-muru'at), dan agama (al-din). Dalam Kamus Besar Bahasa Indonesia, kata akhlak diartikan sebagai budi pekerti atau kelakuan. Kata akhlak walaupun terambil dari Bahasa Arab (yang biasa diartikan tabiat, perangai, kebiasaan, bahkan agama), namun kata seperti itu tidak ditemukan dalam Al-Qur'an, Yang ditemukan hanyalah bentuk tunggal kata tersebut yaitu khuluq yang tercantum dalam Al-Qur'an surat al-Qalam ayat 4. Ayat tersebut dinilai sebagai konsiderans pengangkatan Nabi Muhammad saw sebagai Rasul.

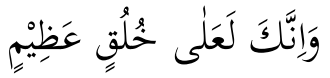

Artinya: Sesungguhnya engkau (Muhammad) berada diatas budi pekerti yang agung" (থS. AlQalam [68] : 4). Kata akhlak banyak ditemukan di dalam hadis-hadis Nabi Muhammad saw, dan salah satunya yang paling populer adalah "Aku hanya diutus untuk menyempurnakan akhlak yang mulia" (HR. Bukhari dan Muslim).

Menurut Muhammad 'Athiyah al-Abrasyi kata 'akhlak' berasal adari Bahasa Arab, jamak dari khuluqun yang menurut Bahasa berarti budi pekerti, perangai, tingkah laku atau tabiat. Kata tersebut mengandung segi-segi persesuaian dengan perkataan Khalqun yang berarti kejadian, yang erat hubungannya dengan Khaliq yang berarti pencipta, demikian pula dengan makhluqun yang berarti yang diciptakan.

Definisi akhlak dari segi istilah dapat merujuk pada pendapat para pakar di bidang ini. Menurut al-Ghazali memberikan definisi akhlak adalah kebiasaan jiwa yang tetap yang terdapat dalam diri manusia, yang dengan mudah dan tidak perlu berfikir (lebih dahulu) menimbulkan perbuatan manusia. (Ismail, 1984, hlm. 2). Pada hakikatnya akhlak menurut al-Ghazali itu harus mencakup dua syarat diantaranya yang pertama kali bahwa perbuatan itu harus konstan, yaitu dilakukan berulang kali kontinu dalam bentuk yang sama, sehingga dapat menjadi kebiasaan (habit forming). Dari definisi tersebut ada kesamaan dalam hal pemahaman makna agar diperoleh suatu konsep penerapan atau pengamalan, yaitu: bahwa akhlak berpangkal pada hati, jiwa atau kehendak, lalu kemudian, dan diwujudkan dalam perbuatan sebagai kebiasaan (bukan perbuatan yang dibuat-buat, tetapi sewajarnya). Sedangkan syarat yang kedua adalah bahwa perbuatan yang konstan itu harus tumbuh dengan mudah sebagai wujud refleksi dari jiwanya tanppa pertimbangan dan pemikiran, yakni bukan karena adanya tekanan-tekanan, paksaan-paksaan dari orang lain atau pengaruh-pengaruh dan bujukan-bujukan yang indah dan sebagainya.

Ditinjau dari segi sifatnya, akhlak terbagi dua macam, yakni akhlak uang baik, disebut akhlakul mahmudah; dan akhlak yang tercela, disebut akhlakul mazmumah. (Barmawie 2001, hlm. 22). Kemudian dilihat dari segi sasarannya, akhlak kepada 
sesame manusia dan akhlak kepada lingkungan. Akhlaqul mahmudah juga terbagi lagi menjadi beberapa macam, diantaranya:

1. Al-Amanah, artinya jujur

2. Al-Afwu, artinya pemaaf

3. Al-Khusu', artinya menghormati tamu

4. Al-Hilmu, artinya tidak melakukan maksiat

5. Al-Adli, artinya bersifat adil

6. Al-Hifafah, artinya memelihara kesucian

7. Ar-Rahman, artinya bersifat belas kasih

8. At-Ta'awun, artinya suka menolong

Selain itu, "Teori pendidikan akhlak" secara teoritis pendidikan akhlak pada dasarnya bertitik tolak dari urgensi akhlak dalam kehidupan. Tokoh yang menganggap pentingnya pendidikan akhlak adalah Oemar Bakry, menurutnya "ilmu akhlak akan menjadikan seseorang lebih sadar lagi dalam tindak tanduknya. Mengerti dan memaklumi dengan sempurna faedah berlaku baik dan bahaya berbuat salah". Mempelajari akhlak setidaknya dapat menjadikan orang baik. Kemudian dapat berjuang di jalan Allah demi agama, bangsa, dan negara. Berbudi pekerti yang mulia dan terhindar dari sifat-sifat tercela dan berbahaya.

Menurut Suwito yang mengutip pendapat M. Amin Abdullah bahwa kalau dibandingkan dengan mazhab pemikiran di bidang pendidikan akhlak maka secara umum pendidikan akhlak dapat dibagi dua, pendidikan akhlak mistik dan pendidikan akhlak rasional. Pembadaan pendidikan akhlak kepada mistik dan rasional bukannya tidak memiliki konsekuensi. Sebagaimana dalam teologi rasional, akhlak rasional dapat membawa konsekuensi bagi pertumbuhan kreativitas dan inisiatif, sedangkan akhlak mistik kurang mendorong manusia untuk dinamis.

Oleh sebab itulah, yang dimaksud dengan pendidikan akhlak rasional yang meberi lebih kuat kepada pendidikan daya pikir rasio) manusia, sedanfgkan pendidikan akhlak mistik memberikan porsi lebih kuat kepada pendidikan daya rasa pada diri manusia. Distingsi ini bermanfaat bagi konsekuensi yang ditimbulkan. Konsekuensi pada pendidikan akhlak rasional memberikan dorongan kuat bagi terciptanya manusia dinamis. Adapun konsekuensi yang diperoleh dari pendidikan akhlak mistik kurang memberikan dorongan kuat bagi terciptanya manusia yang dinamis.

Namun, pendidikan akhlak tidak masuk dalam kategori institusi sebagaimana diatas, karena hakikat pendidikan akhlak adalah inti semua jenis pendidikan. Pendidikan akhlak mengarah pada terciptanya perilaku lahir dan batin manusia sehingga menjadi manusia yang seimbang dalam arti terhadap dirinya maupun terhadap luar dirinya. Dengan demikian, pendekatan pendidikan akhlak bukan monolitik dalam pengertian harus menjadi nama bagi suatu mata pelajaran atau lembaga melainkan terintegrasi ke dalam berbagai mata pelajaran atau lembaga.

$\overline{\text { Al-Madãris, Volume 2 (2), } 2021}$ 
Penjelasan diatas menggiring pemahaman bahwa istilah pendidikan akhlak adalah "suatu kegiatan pendidikan yang disengaja untuk perilaku lahir dan batin manusia menuju arah tertentu yang dikehendaki".

\section{Metodelogi}

Penelitian ini menggunakan jenis penelitian studi pustaka (library research). Pendekatan yang digunakan dalam penelitian ini adalah pendekatan historis. Melalui kesinambungan historis, dilihat benang merah dalam pemikiran tokoh, baik yang berkaitan dengan lingkungan historis dan pengaruh-pengaruh yang dialaminya, maupun dalam perjalanan hidupnya sendiri. Sedangkan penelitian studi pustaka (library research) yaitu mengumpulkan data atau karya tulis ilmiah yang bertujuan dengan objek penelitian atau pengumpulan data yang bersifat kepustakaan atau telaah yang dilaksanakan untuk memecahkan suatu masalah yang apada dasarnya tertumpu pada penelaahan kritis dan mendalam terhadap bahan-bahan pustaka yang relevan.

Berikutnya, sumber data yang digunakan dalam penelitian ini ialah sumber primer dan sekunder. Dimana sumber primer adalah sumber-sumber yang memberikan data secara langsung dari tangan pertama atau sumber asli. Dalam penulisan penelitian ini sumber primer yang dimaksud adalah buku prinsip-prinsip pemikiran Ulama Besar Sufi Turki Badiuzzaman Said Nursi tentang pendidikan akhlak generasi muda dan kitab Ta'lim Muta'alim karya Syekh Burhanuddin AlZarnuji. Sedangkan sumber sekunder adalah sumber-sumber yang diambil dari sumber lain yang tidak diperoleh dari sumber primer. Dalam penulisan penelitian ini sumber sekunder yang dimaksud adalah sumber pendukung yang terkait dan relevan dengan sumber primer untuk kemudian dipertemukan dalam penelitian.

Untuk metode pengumpulan data peneliti menggunakan metode dokumentasi. Studi dokumentasi menurut Suharsimi Arikunto adalah mencari data mengenai hal-hal atau variavel berupa catatan, buku, transkip, surat kabar, majalah, dan lain sebagainya. Tujuan penelitian ini adalah untuk mengeksplorasi atau mengungkap studi komparasi konsep pendidikan akhlak menurut Badiuzzaman Said Nursi dan konsep pendidikan akhlak menurut Syekh Burhanuddin Al-Zarnuji dengan menggunakan analisis kualitatif, berupa teori-teori, konsep-konsep, pernyataan-pernyataan beberapa ahli yang memiliki relevansi dengan masalah yang diatas dimana penyajiannya bersidat deskriptif dengan menggunakan metode induktif dan deduktif.

Proses berfikir induktif tidak banyak artinya kalu tidak diikuti proses berfikir yang deduktif. Sebab itu generalisasi hanya akan mempunyai makna yang penting, kalau kesimpulan yang di turunkan dari sejumlah fenomena tadi bukan saja mencakup semua fenomena itu, tetapi juga harus berlaku pada fenomena lain yang sejenis yang belum diselidiki. Berikutnya untuk proses analisis data, penulis menggunakan metode analisis isi (content analysis). Content analysis adalah suatu metode penelitian yang membuat referensi-referensi yang dapat ditiru dan shahih data dengan memperhatikan konteksnya. Selain itu, penelitian ini juga menggunakan 
analisi data induksi dan deduksi. Induksi pada umumnya disebut generalisasi. Induksi dapat berupa pengumpulan fakta-fakta yang ditemukan, kemudian dirumuskan ucapan umum. Pada pelaksanaan induksi filosofis ini, yang universal ditemukan didalam yang singular. Deduksi, berupa penjelasan dari pemahaman universal, dengan demikian generalisasi dikaji kembali apakah memang sesuai.

\section{Hasil Penelitian dan Pembahasan}

1. Definisi Pendidikan Akhlak

Pendidikan akhlak generasi muda menurut Said Nursi adalah "Suatu komitmen yang mendalam mengenai kehidupan menuju arah terciptanya perilaku lahir dan batin yang seimbang (seperti Nabi) bagi generasi muda menurut pemahaman Badiuzzaman Said Nursi". Hal ini berarti bahwa Said Nursi memiliki pemahaman tentang komitmen-komitmen yang mendalam mengenai kehidupan menuju arah yang diinginkan yaitu berperilaku seperti Nabi, yang sangat bermanfaat bagi generasi muda.

Disisi lain, Pendidikan akhlak menurut kitab Ta'lim Muta'alim adalah menanamkan akhlak mulia serta menjauhkan diri dari akhlak tercela dan mengetahui gerak gerik hati yang dibutuhkan dalam setiap keadaan, ini wajib diketahui seperti tawakal, al-inabah, taqwa, ridha, dan lain-lain.

\section{Tujuan Pendidikan Akhlak}

Tujuan pendidikan akhlak menurut Ulama Badiuzzaman Said Nursi adalah bahwa tujuan tertinggi dan hasil termulia dari makhluk itu adalah keimanan kepada Allah swt. Said Nursi menyatakan bahwa "Hati nurani diterangi oelh ilmu-ilmu agama, sedangkan kecendikaan diterangi oleh ilmu-ilmu peradaban". Dimana betapa luasnya ruang lingkup dan sasaran yang harus dicapai pendidikan Islam. Namun demikian, patokan yang dipegang bahwa intinya untuk memperoleh kesejahteraan hidup di dunia dan akhirat.

Selain itu, Pemikiran Al-Zarnuji tentang tujuan pendidikan adalah untuk mencari Ridho Allah, memperoleh kebahagiaan di akhirat, berusaha memerangi kebodoan pada diri sendiri dan orang lain, mengembangkan dan melestarikan ajaran Islam serta menyusuri nikmat Allah. Dibalik itu semua, tujuan pendidikan akhlak tidak lepas dari tujuan ideal dan tujuan operasional. Tujuan ideal biasanya disesuaikan dengan tujuan hidup manusia. Pendapat tersebut dilandaskan karena manusia untuk mencapai tujuan hidup memerlukan pendidikan formal maupun norformal. Sedangkan tujuan operasional adalah suatu kondisi yang ingin dicapai pada setiap tahap dalam proses pendidikan yang sedang dilangsungkan.

\section{Konsep Pemikiran}

a. Konsep Pemikiran Badiuzzaman Sais Nursi tentang Prinsip-Prinsip Pendidikan Akhlak

1) Menguatkan Iman

Iman bagi manusia sangat penting. Said Nursi memperhatikan secara intensif mengenai keimanan ini, sehingga menjadi komitmen mendasar baginya. "Prinsip

$\overline{\text { Al-Madãris, Volume 2 (2), } 2021}$ 
menguatkan Iman" ini benar-benar menjadi dasar bagi setiap orang. Dengan kata lain, keimanan dapat dipahami sebagai akidah atau tauhid. Dalam konteks tauhid ini Ismail Raji' Al-Faruqi menyatakan bahwa "esensi pengamalan keagamaan dalam Islam adalah tauhid yaitu pengakuan bahwa tidak ada Tuhan selain Allah (La illaha illa Allah)". Pendapat ini menguatkan bahwa sebagian pengalaman hidup adalah pengalaman keagamaan. Dimana pengalaman keagamaan cenderung semakin meningkatkan diri kepada Sang Maha Kuasa. Dalam konteks ajaran Islam, maka keimanan mendalam meyakini secara penuh adanya Allah swt, itulah yujuan ciptaan tertinggi manusia.

Menurut Said Nursi hakikat keimanan terdapat dalam kalimat La ilaha illaha yang berarti mengakui secara totalitas kekuasaan Allah swt. Mengenai ini Said Nursi menganggap bahwa "segala sesuatu selain Allah tidaklah berasal dari sesuatu itu sendiri tetapi berasal dari Allah Ynag Maha Kuasa. Menganggap alam semesta berasal dari alam semesta itu sendiri atau kuasa-kuasa material itu adalah suatu kesalahan.

Segala sesuatu mempunyai dua aspek: aspek pertama mengacu kepada Pencipta sedangkan aspek yang kedua mengacu kepada ciptaan". Selanjutnya dapat diyakini bahwa sebenarnya keimanan menjadi komitmen dasar dalam berakhlak. Dalam pandangan Islam, akhlak merupakan cerminan dari apa yang ada dalam jiwa (al-qalb mir'u al'amal). Akhlak yang baik terdorong dari keimanan seseorang karena sesungguhnya iman selain diyakini dalam hati, juga harus ditampilkan dalam perilaku nyata sehari-hari. Keyakinan Tauhid yang terangkum dalam rukun iman seharusnya menjiwai dalam kehidupan manusia. Pendapat ini menguatkan bahwa kunci dari akhlak adalah keimanan.

Said Nursi juga mengutip pendapat Imam Rabbani - pemimpin yang berpengaruh dan mursyid yang terkemuka dari aliran nakshabandiah - mengatakan dalam suratnya, "Aku lebih suka perkara keimanan diketahui dengan cara yang mudah dimengerti daripada mencapai ribuan kenikmatan dan pencapaian rohani, ataupun melakukan keajaiban-keajaiban". Singkatnya, menguatkan keimanan berupaya menegaskan bahwa tingkat keimanan yang pokok melalui pengalaman langsung dan berkomunikasi dengan orang lain untuk memahami Islam secara integral, baik alam semesta, manusia dan Tuhan.

Hal ini juga berarti bahwa secara tersirat dan tersurat Said Nursi meyakinkan kepada seluruh manusia terlebih lagi generasi muda bahwa prinsip "menguatkan keimanan" harus dilakukan oleh setiap manusia secara keseluruhan di akhir abad ini secara bertahap dan istiqomah dan keimanan mengajarkan untuk mengobati penyakit hati nurani.

2) Berpegang Teguh Pada Al-Qur'an

Al-Qur'an berperan sebagai pedoman dan petunjuk menuju kebenaran Allah swt. Prinsip berpegang teguh pada Al-Qur'an menjadi komitmen dasar bagi Said Nursi. Berpegang teguh pada Al-Qur'an berarti manusia dituntut untuk mencapai kesempurnaan menuju Allah swt. Sedikitnya ada tiga pertanyaan untuk memperkuat argument ini: Apa sebenarnya Al-Qur'an? Mengapa Al-Qur'an menjadi pedoman? Mengapa Al-Qur'an menjadi sangat penting dalam mengenal Allah? Ketiga 
pertanyaan ini sangat penting dijawab, karena secara faktual tanpa ada Al-Qur'an maka manusia tidak akan mengenal Allah sebagai Penciptanya.

Al-Qur'an adalah wahyu Allah atau kalam Allah swt. Al-Qur'an merupakan wahyu Allah swt yang Agung dan bacaan mulia serta dapat dituntut kebenarannya oleh siapa saja, sekalipun akan menghadapi tantangan kemjuan ilmu pengetahuan yang semakin canggih (Syafi'I 2003, hlm. 53). Menurut Said Nursi Al-Qur'an berasal dari Pencipta langit beserta benda-benda langit dan bumi serta seluruh penghuninya. Al-Qur'an yang membuat kita mengenal Tuhan semua alam.

Al-Qur'an merupakan pendiri: ia adalah dasar dari agama yang nyata, dan fomdasi dunia Islam. Ia dating untuk mengubah kehidupan sosial manusia dan untuk menjawab pertanyaan-pertanyaan yang sering diajukan dari kelas-kelas sosial yang berbeda. Kemudian Al-Qur'an berbicara tentang hal-hal penting itu dan kebenarankebenaran yang sulit dipahami, sehingga diperlukan pengulangan di dalam konteks yang berbeda untuk membuat pikiran dan kalbu manusia terkesan dalam aspekaspeknya.

Demikian, yang mendasari komitmen Said Nursi dalam berpegang teguh pada Al-Qur'an dapat ditegaskan bahwa dalam konteks ini berarti Al-Qur'an merupakan informasi yang menjelaskan tentang pentingnya tauhid atau keimanan sebagai rangkaian mengkokohkan keyakinan. Kemudian, pentingnya Al-Qur'an sebagai kalam Allah, karena menceritakan dan mendeskripsikan secara implisit tentang proses penciptaan manusia dan proses penciptaan alam semesta, yang memperkuat pemahaman mengenaai manusia, alam dan Tuhan. Pentingnya, informasi Al-Qur'an sebagai dan sumber rujukan bagi akhlak untuk membentuk pribadi yang berakhlak. Sebab, melalui Al-Qur'an manusia memperoleh petunjuk, jalan, pedoman dan sumber kehidupan bagi berakhlak mulia.

3) Pentingnya Memahami Hakikat Penciptaan Manusia

Prinsip pentingnya memahami hakikat penciptaan manusia senantiasa berkaitan dengan memahami makna hidup dalam konteks ajaran Said Nursi. Karena dengan prinsip ini manusia mengerti keberadaan dirinya di muka bumi ini. Kehadiran manusia dibumi ini memiliki beragam pertanyaan. Bahkan hampir sepanjang hidupnya manusia harus belajar keberadaan dirinya.

Menurut keterangan Ibn Maskawaih bahwa unsur al-nafs al-bahimiyyat (daya nafsu) dan al-nafs al-sabu'iyyat (daya berani) berasal dari unsur materi akan hancur bersama hancurnya badan. Sedangkan al-nafs nathiqat (daya pikir) tidak akan mengalami kehancuran. Sesuai dengan pemahaman ini Said Nursi mengapresiasi daya-daya itu dalam sifat-sifat mulia manusia yang menjadi doktrin-doktrin utamanya.

4) Pentingnya Memahami Alam Semesta

Said Nursi dalam Risalah An-Nur mengatakan "Mengapa Al-Qur'an tidak membahas alam semesta seperti yang dibahas dalam filsafat dan sains modern?" Pertanyaan ini sekaligus menjelaskan kalua Said Nursi meyakini bahwa alam semesta merupakan manifestasi dari nama-nama Allah swt. Yang harus dijadikan komitmen mendasar dalam membina diri untuk memperoleh jalan kesempurnaan menuju Allah

$\overline{\text { Al-Madãris, Volume 2 (2), } 2021}$ 
swt. Maka dari itu, Said Nursi sangat yakin bahwa penciptaan alam semesta adalah bukti keesaan, kebesaran Allah swt.

Sehingga jelas bahwa alam semesta sebagai makrokosmos "big creation" adalah bukti kebesaran asma Allah. Pemahaman terhadap alam ini bagian dalam upaya, meningkatkan untuk pembinaan akhlak. Ketika kita mengetahui, mengerti dan memahami bahwa Allah sebagai Pencipta alam, maka ketika melihat alam semesta akan berpengaruh dalam tingkah laku, sikap dan cara berpikir kita dan mendorong jiwa untuk beriman secara istiqomah dan totalitas kepada Allah swt.

5) Pentingnya Memahami Asma' Al-Husna

Prinsip pentingnya memahami asma' al-husna menjadi komitmen mendasar bagi Said Nursi karena, di kitab Tafsir Risalah An-Nur bila dicermati scera mendalam dibahas oleh Said Nursi hamper di semua kitabnya secara terintegrasi. Tapi, secara khusus Said Nursi menjelaskan asma' al-husna dalam kitab Lem'alar pada "Cahaya Ketiga Puluh berjudul Asmma; Al-Husna". Kita tahu bahwa dalam, pandangan ulama asma' al-husna berjumlah 99 nama-nama Allah. Namun, menurut Said Nursi dalam "Cahaya Ketiga Puluh" menjelaskan bahwa Allah memiliki al-ismu al-Azhom (namanama Allah yang paling agung.

Dapat dipahami bahwa asma' al-husna Said Nursi memiliki kecenderungan sama dengan ulama masa lalu yang meyakini 99 nama-nama Allah, namun dari segi metode penerapan pandangan terjadi perbedaan. Said Nursi cenderung memandang ada 6 (enam) nama-nama Allah yang dikategorikan sebagai asma'ul adzam (Nama yang Agung) yaitu al-Quddus, al-Adl, al-Hakim, al-Fard, al-Hai, dan al-Qayyum dan Said Nursi yakin sifat-sifat Allah adalah bentuk manifestasi dari asma'al-husna. Manifestasi pemahaman asma' al-husna penting dalam pembentukan manusia yang berakhlak dan asma' al-husna menjadi landasan diri berkepribadian akhlak mulia.

6) Pentingnya Mengetahui Tanda-Tanda Akhir Zaman

Prinsip pentingnya mengetahui tanda-tanda akhir zaman menjadi bagian yang mendorong peningkatan keimanan bagi Said Nursi, karena manusia sekarang sudah memasuki fase penghbisan dari panjangnya zaman yang sudah lama berlalu. Adapun tanda-tanda akhir zaman yaitu:

a) Munculnya Dajjal dan Sufyan

b) Munculnya Messiah atau Mahdi

c) Mengenai Terbentuknya Padang Mahsar

Adanya tanda-tanda akhir zaman memberikan keyakinan yang kokoh terhadap paham keagamaan dengan keimanan yang sudah ada sebagai dasar beragama. Seiring dengan itu, hari kiamat menjadi bagian yang terintegrasi dalam diri Said Nursi dan salah satu cara upaya pembentukan akhlak mulia.

7) Pentingnya Meyakini Hari Kiamat

Serangkaian upaya pembentukan manusia yang berakhlak mulia, pemahaman tentang hari kiamat banyak dirujuk sebagai bagian pembentukan karakter bagi Said Nursi. Para pemikir Islam dulu baik yang sezaman dengan Said Nursi maupun sebelumnya belum menafsirkan secara mendalam mengenai ayat-ayat dan hadishadis mengenai hari kiamat. Hari kiamat menjadi landasan fundamental dalam

$\overline{\text { Al-Madãris, Volume 2 (2), } 2021}$ 
pemikiran Said Nursi. Karena itu, hari kiamat menjadi prinsip yang dapat mendorong terciptanya akhlak mulia yang menekankan sisi-sisi kejiwaan manusia.

8) Meneladani Nabi Muhammad Saw

Prinsip meneladani Nabi Muhammad Saw menjadi komitmen dasar Said Nursi dalam merealisasikan ajaran-ajaran Islam dalam kehidupan sehari-hari untuk mencapai kebahagiaan hidup di dunia dan akhirat. Pada prinsipnya bahwa mengamalkan Sunnah-sunnah Nabi Muhammad Saw dengan sepenuhnya merupakan cerminan dari keseriusan mentaati perintah Allah Swt dan menjauhi segala larangannya dengan mengikuti Al-Qur'an dan keimanan mendalam akan keesaan Allah.

Pada dasarnya, apabila seseorang menyatakan diri sebagai muslim, maka ia harus mewujudkan keislamannya itu dalam bentuk mengikuti Sunnah Nabi tersebut secara sungguh-sungguh dalam segala aspek kehidupan. Dengan prinsipnya ini, Said Nursi hendak menegaskan bahwa bila seseorang yang telah berikrar bahwa dirinya adalah pengikut Muhammad Rasul-Allah Saw, hendaknya ia harus mengikuti cara atau metode dan jalan hidup yang telah dibuat oleh Nabi Muhammad Saw bersama para sahabatnya dalam seluruh aspek kehidupan.

9) Menanamkan Ikhlas, Takwa dan Sedekah

Said Nursi sangat menekankan kepada murid-muridnya untuk senantiasa ikhlas, takwa, dan sedekah. Said Nursi sangat yakin keikhlasan, ketakwaan, dan sedekah dapat membentuk karakter pribadi manusia. Dimana ketiga hal ini menjadi dasar hidup dalam pembentukan manusia ideal dalam pandangan Said Nursi yang diisyaratkan secara implisit dalam Risalah An-Nur untuk membentuk manusia ideal yang berakhlak mulia.

a) Ikhlas menjadikan manusia filosof-sufi

b) Takwa menjadikan manusia Ulil Albab

c) Sedekah menjadikan manusia Dermawan

\section{b. Konsep Pendidikan Akhlak dalam Kitab Ta'lim Muta'alim}

Setiap cabang ilmu harus diiringi dengan akhlak yang baik. Al-Zarnuji juga berpendapat bahwa kurangnya akhlak hanya dapat menghilangkan ilmu. Karena akhlak sejajar dengan iman, tauhid, dan syariat. Tauhid itu menyebabkan iman, barang siapa tidak mempunyai iman berarti tidak bertauhid. Iman juga menyebabkan syari'at, maka barngsiapa tidak melaksanakan syari'at berarti tidak beriman dan tidak bertauhid. Syari'at menyebabkan akhlak, maka barang siapa yang tidak mempunyai akhlak berari tidak bersyari'at, tidak beriman dan tidak bertauhid.

Pendidikan akhlak yang ditekankan oleh Al-Zarnuji dalan Kitabnya Ta'lim Muta'alim membagi menjadi tiga kategori akhlak, yaitu:

1. Akhlak Kepada Allah

Bahwa hendaknya aktivitas guru dan murid dalam belajar mengajar diniatkan kepada Allah semata, bukan karena tujuan duniawi saja, karena banyak amal perbuatan yang bentuknya duniawi kemudian menjadi amal akhirat karena bagus niatnya begitu pula sebaliknya banyak amal akhirat menjadi perbuatan amal 
duniawi saja sebab sudah salah dalam jiatnya, kemudian menyerahkan semua urusan kepada Allah serta memohon petunjuk-Nya, menerima apa adanya pemberian Allah dan sabar dengan segala kondisi dirinya.

Akhlak yang baik harus dipenuhi untuk setiap penuntut ilmu terutama kepada Allah Swt supaya mendapatkan ilmu yang bermanfaat. Kemudian bersyukur atas apa yang diberikan kepada kita baik kenikmatan akal dan kesehatan badan dengan cara bersyukur dengan lisan, hati, perbuatan dan hatinya. Disebutkan bahwa Abu Hanifah ra berkata: "aku mendapat ilmu dengan hamdalah dan bersyukur, setiap aku diberi taufiq untuk memahami fiqih dan hikmah lalu aku mengucap "Alhamdulillah" maka bertambahlah ilmuku.

Apabila seseorang telah mendapatkan ilmu, entah seberapa banyak ilmu yang didapatnya dengan susah payah, maka jangan samapi membelokkan ilmunya demi kepentingan duniawi yang hina saja. Seorang yang berilmu harus bias mengamalkan apa yang ia peroleh, salah satunya dengan beramar ma'ruf bahi munkar, memperjuangkan kebenaran dan meluhurkan agama bukan untuk kepentingan hawa nafsu diri sendiri.

2. Akhlak Kepada Sesama Manusia

Terdapat tiga penerapan akhlak atau sikap kepada manusia yang diajarkan dalam kitab Ta'lim Muta'alim, yakni:

a) Berakhlak pada diri sendiri, maksudnya sebagai seorang pencari ilmu kita harus membenahi diri terlebih dahulu. Karena ilmu merupakan sesuatu yang istimewa dan bukan hal sembarangan, yang membedakan antara manusia dengan makhluk lain. Oleh karena itu, setiap manusia harus mempelajari mengenai akhlak, seperti dermawan, kikir, penakut, nekat, sombong, rendah diri, menjaga diri, berlebih-lebihan dan lain sebagainya. Ketika sudah memahami tentang ilmu akhlak maka seorang penuntut ilmu harus bias menerapkan akhlak baik dan manjauhi akhlak buruk.

b) Akhlak dari seorang murid terhadap guru. Dimana pun guru dipandang sebagai pribadi yang sangat dihormati. Di dalam kitab ini pun, Al-Zarnuji berwasiat diantara cara memuliakan guru adalah:

1) Tidak melintas dihadapannya

2) Tidak menduduki tempat duduknya

3) Tidak memulai bicara kecuali atas ijinnya

4) Tidak banyak bicara disebelahnya

5) Tidak menanyakansesuatu yang membosankan

6) Hendaklah pula mengambil waktu yang tepat dan jangan pernah mengetuk pintu tetapi bersabarlah sampai beliau keluar.

c) Akhlak murid terhadap teman senasib seperjuangan juga perlu mendapat perhatian, karena dari sini akan tercipta sebuah pemahaman bahwa murid mempunyai akhlak yang baik kepada teman sesamanya, sikap saling menghormati dan menghargai satu sama lain. Namun dalam memilih teman hendaklah memilih orang yang tekun, wira'I, berwatak jujur dan mudah

$\overline{\text { Al-Madãris, Volume 2 (2), 2021 }}$ 
memahami masalah; hendaklah menjauh dari orang yang pemalas, pengangguran, suka banyak bicara, suka mengacau dan gemar memfinah.

3. Akhlak Kepada Ilmu

Dalam mencari ilmu seeorang akan dihadapi berbagai rintangan, karena tak semudah membalikkan telapak tangan. Ali bin Abi Thalib pernah bersyair yang artinya: "Ingatlah, tidak akan kalian mendapat ilmu yang bermanfaat, kecuali dengan enam syarat: cerdas, semangat, sabar, biaya, petunjuk guru, dan waktu yang lama".

Selain syarat tersebut, pencari ilmu juga harus berdoa kepada Allah Swt supaya diringankan rintangannya dan menganugrahkan ketabahan dan kesabaran. Al-Zarnuji dalam kitabnya bahwa sabar dan tabah adalah pangkal yang besar untuk segala urusan, terutama dalam berguru, dalam mempelajari suatu kitab jangan ditinggalkan terbengkalai. Maksudnya jangan berpindah kepada kitab atau pembelajaran lain sebelum yang pertama sempurna dipelajari.

4. Relevansi Pemikiran Ulama Badiuzzaman Said Nursi dan Kitab Talim Muta'alim terhadap Pendidikan Akhlak Generasi Muda

Ide dan dasar keyakinan beragama yang diterima generasi muda dari masa kanak-kanaknya sudah tidak begitu menarik bagi mereka. Sifat kritis terhadap ajaran agama mulai timbul. Selain masalah agama mereka pun sudah tertarik pada masalah kebudayaan, sosial, ekonomi, dan norma-norma kehidupan lainnya.

Walau sulit mengukur tingkat keimanan bagi generasi muda, namun kekuatan iman akan sangat Nampak dari tingkah laku dan peribadahan yang dilakukan. Namun, Said Nursi sangat menekankan keimanan bagi generasi muda. Tujuan ciptaan yang paling murni dan fitrah manusia yang paling tinggi adalah iman kepada Allah. Jika ditinjau dari aspek pengamalan agama, tawaran-tawaran Said Nursi adalah penguatan keimanan melalui ruh ketauhidan masuk dalam kehidupan manusia ke relung batin. Tauhid adalah dasar utama dalam menyatakan keimanan secara sempurna. Hakikat keimanan secara menyeluruh dapat dipahami melalui rukun iman yaitu; Rukun ian terdiri dari iman kepada Allah, malaikat-malaikat-Nya, Kitab-kitab-Nya, Rasul-rasul-Nya, Hari Kiamat, dan Qadha dan Qadhar.

Prinsip keimanan yang ditanamkan Said Nursi dalam dirinya dan muridmuridnya sangat relevan untuk selalu direalisasikan oleh generasi muda yang beriman, Walaupun tidak diketahui secara tepat tingkat keimanan generasi muda tersebut. Namun, diyakini bahwa dengan senantiasa menguatkan keimanan akan tercapai keinginan insan shaleh.

Cita-cita dari pandangan hidup Said Nursi daam konteks pendidikan akhlak adalah manusia ideal dalam sebagaimana Risaah An-Nur adalah manusia yang dekat dengan Allah dan berperilaku seperti Nabi Muhammad saw. Istilah yang sering digunakan Said Nursi adalah "Hizmetul Iman wa Al-Qur'an", menurutnya sekarang ini adalah akhir zaman dan menyadarkan umat dari paham duniawi ke ukhrawi.

Prinsip menguatkan keimanan diperlukan bagi generasi muda untuk melawan pandangan-pandangan hidup yang dapat merusak akidah generasi muda. Said Nursi meyakinkan generasi muda dengan mengatakan: "Zat yang menggenggam 
kendali semua unsur di alam ini pastilah juga memegang kendali semua unsurnya”. Generasi muda harus yakin bahwa kendali dalam kehidupan ini diciptakan sang pencipta yaitu Allah Swt. Dan sekaligus memegang secara penuh kendali kehidupan ini.

Said Nursi juga memberikan perhatian kepada situasi kejiawaan generasi muda dengan menanamkan nilsi-nilai akidah dan iman bertujuan untuk menyiapkan generasi muda sejak dini, ketangguhan mereka untuk memperlemah sumber penyakit jiwa, misalnya marah, takut mati, dan kesedihan. Sehingga, ketika pada masanya para generasi muda itu sudah bear-benar siap dalam menghadapi kehidupan yang luas ini. Sementara itu, dizaman sekarang ini, tentu berbeda dengan pada saat Al-Zarnuji masih menuntut ilmu. Dengan realita yang ada saat ini banyak sekali kita lihat bahwa moral atau akhlak sudah tidak diperhatikan lagi. Orangtua hanya melihat hasil pendidikan yang dapat dilihat oleh mata saja bukan dari akhlak dari seorang anak. Lembaga pendidikan seharusnya mendidik anak dalam bidang jasmani dan rohani secara seimbang supaya tercipta anak bangsa yang unggul dalam berakhlak. Akan tetapi sekarang berubah makna, anak yang berpendidikan belum tentu berakhlak baik. Sudah bukan hal yang tabu lagi, sekarang ini mereka berpendidikan tinggi, bahkan tak jarang mereka lulusan dari perguruan tinggi di luar negeri namun mereka tak sedikit yang kering akan aspek spiritual terutama akhlak.

Pemikiran-pemikiran dari seorang Al-Zarnuji cukup relevan untuk mengembalikan pendidikan pada fungsinya. Melihat dunia pendidikan sekarang sangat ironis banyak seorang pendidik atau guru yang sudah kehilangan wibawa dan disegani oleh murid-muridnya, alhasil banyak guru yang dilaporkan muridnya dengan tuduhan kekerasan kepada murid, padahal bila melihat hal yang dilakukan guru adalah sebuah peringatan kepada muridnya supaya muridnya menjadi seseorang yang lebih baik. Oleh karena itu, konsep hubungan antara guru yang berwibawa namun tetap akrab dengan murid harus ada. Wibawa seorang guru dan akrab dengan murid adalah dua unsur yang sangat esensial untuk membentuk lingkungan pendidikan yang baik, benar dan sehat. Seorang guru yang berwibawa, disegani dan akrab dengan murid akan mampu membentuk kepribadian seorang murid dalam hal akhlak yang bukan sekedar memberi pelajaran yang meningkatkan intelektual saja.

Ketaatan kepada guru dan orangtua harus ditanamkan sejak awal. Karena akan membentuk kepribadian seorang anak dalam menuntut ilmu. Seorang murid yang ta'dzim dengan guru dia akan dipermudah dalam segala hal, seperti proses masuknya ilmu yang diberikan seorang guru kepada murid. Selain itu seorang pencari ilmu harus berakhlak baik terhadap diri sendiri dan kepada temantemannya. Oleh karena itu, lembaga pendidikan diIndonesia khususnya, harus bisa memproduksi calon-calon pemimpin bangsa yang kaya akan moral dan akhlak yang baik sesuai kaidah-kaidah Islam. Karena apabila akhlak sudah baik secara otomatis hal apapun akan membaik. Walaupun hal tersebut tidak mudah, berbagai elemen harus saling mendukung baik lingkungan keluarga, lingkungan masyarakat dan lingkungan pendidikan.

$\overline{\text { Al-Madaris, Volume 2 (2), } 2021}$ 


\section{E. Kesimpulan}

Berdasarkan penjelasan yang sudah di uraikan diatas maka dapat disimpulkan bahwa konsep pemikiran Ulama Badiuzzaman Said Nursi dan Kitab Ta'lim Muta'alim karya Syeikh Burhanuddin Al-Zarnuji sangat relevan dengan fenomena pendidikan akhlak generasi muda zaman sekarang. Walaupun memiliki konsep yang berbeda namun pada intinya ada beberapa persamaan yang menjadi akar dari pemikiran keduanya. Konsep pendidikan akhlak menurut Ulama Badiuzzaman Said Nursi memiliki Sembilan prinsip dasar yaitu: menguatkan iman; berpegang teguh pada Al-Qur'an; pentingnya memahami hakikat penciptaan manusia; pentingnya memahami alam semesta; Pentingnya memahami Asma'ul Husna; pentingnya mengetahui tanda-tanda akhir zaman; pentingnya meyakini Hari Kiamat; meneladani Nabi Muhammad saw; menanamkan ikhlas, takwa, dan sedekah. Prinsip-prinsip ini saling berkaitan dalam jiwanya dan sifatnya tidak dapat dipisahpisahkan. Baik dalam pola pikir, pola sikap dan pola lakunya. Prnsip-prinsip pendidikan akhlak Said Nursi dapat dikatakan sebagai prinsip-prinsip pendidikan akhlak generasi muda. Tentu saja, karena sifatnya filosofis dalam diri manusia, maka prinsip-prinsip ini menjadi dasar bagi Said Nursi yang sangat relevan dengan kehidupan generasi muda. Sedangkan konsep pendidikan akhlak menurut kitab Ta'lim Muta'alim terkandung nilai-nilai akhlak yang berupa akhlak kepada Allah swt, akhlak kepada manusia dan akhlak terhadap ilmu. Keduanya sama-sama menjawab tantangan pendidikan akhlak generasi muda karena dengan pemikiran tersebut para generasi muda dapat memperbaiki akhlak sehingga tidak hanya cerdas pikir namun juga cerdas sikap.

\section{BIBLIOGRAFI}

Afriantoni. (2015). Prnsip-Prinsip Pendidikan Akhlak Generasi Muda: Percikan Pemikiran Ulama Sufi Turki Badiuzzaman Said Nursi. Yogyakarta: Deepublish.

Alim, Muhammad. (2011). Pendidikan Agama Islam; Upaya Pembentukan Pemikiran dan Kepribadian Muslim. Bandung: Rosdakarya.

Al-Attas, Syed Muhammad Naquib. (1999). Islam dan Filsafat Sains (diterjemahkan oleh Saiful Muzani. Bandung: Mizan.

Al Zarnuji, t. th, Ta'limul Muta'alim.

Anwar, Saifuddin. (1998). Meteodologi Penelitian. Yogyakarta: Pillar Offset.

Arikonto, Suharsimi. (2002). Prosedur Penelitian. Jakarta: PT Rineka Cipta.

As'ad, Aliy. (2007). Terjemah Ta'limul Muta'alim. Kudus: Menara Kudus.

Azra, Azyumardi. (2000). Pendidikan Islam (Tradisi dan Modernisasi Menuju Milinium Baru. Jakarta: Logos.

Bekker, Anton Bekker \& Achmad Charris Zubair. (1990). Metode Penelitian Filsafat. Yogyakarta: Kanisius.

Bhareisj, Hussein j. (1980). Himpunan Pengetahuan Islam (450 Masalah Agama Islam). Surabaya: Al-Ikhlas. 
Bisri, Mustofa. (1994). Saleh Ritual, Saleh Sosial: Esai-esai Moral. Bandung: Mizan.

Departemen Agama RI. 2002. Al-Qur'an Al-Karim dan Terjemahannya. Semarang: PT Karya Toha Putra.

Departemen Agama RI dan Mesir 1997. Al-Qur'an dan Terjemahnya. Mushraf Asyarifah, Madinah Al Munawarah.

Https://www.asadiyahdapoko.com/2020/07/20/pendidikan-akhlak-menurut-syekhal-zarnuji-dalam-kitab-talimul-

mutaallim/\#:: :text=Menurut\%20Az\%2DZarnuji\%20pendidikan\%20akhlak,ri dha\%2C\%20dan\%20lain\%2Dlain

Keraf, Gorys. (2010). Argumentasi dan Narasi. Jakarta: PT Gramedia Pustaka Utama.

Krippendorf, Klaus. (1991). Analisis Isi. Jakarta: Rajawali Pers.

Ma'arif, Ahmad Syafi'i. (2000). Krisis dalam Pendidikan Islam. Jakarta: Al-Mawardi Prima

Mahmud, Ali Abdul Halim. (2004). Akhlak Mulia. Jakarta: Gema Insani.

Mustafa, A. (1999). Akhlak Tasawuf. Bandung: CV Pustaka Setia.

Nasution. (2001). Metode Research Penelitian Ilmiah, Edisi I. Jakarta: Bumi Aksara.

Noerhidayatullah. (2002). Insan Kamil: Metode Islam Memanusiakan Manusia. Bekasi: Intimedia dan Nalar.

Nursi, Badiuzzaman Said Nursi. (2003a). Risalah An-Nur: Said Nursi: Pemikir dan Sufi Besar Abad 20 (Menikmati Takdir Langit: Lama'ar. Jakarta: Murai Kencana.

Nursi, Badiuzzaman Said. (2004a). Mengokohkan Akidah Menggairahkan Ibadah, (Diterjemahkan oleh Muhammad Misbah). Jakarta: Robbani Press.

Pimay, Awaluddin. (1999). Konsep Pendidik dalam Islam (Studi Komparasi atas pandangan Al-Ghozali dan Al-Zarnuji). Semarang. Tesis PPS IAIN Walisongo Semarang.

Qabbani, Marwan. (1981). Syeikh Al-Zarnuji. Beirut: Dar Al Maktab Al Islami.

Suwito. (1995). “Konsep Pendidikan Akhlak Menurut Ibn Maskawaih". Jakarta: Disertasi Doktor pada Program Pascasarjana (Pps) Institut Agama Islam Negeri (IAIN) Syarif Hidayatullah.

Thaib, Ismail. (1984). Risalah Akhlak. Yogyakarta: Bina Usaha.

Zainuddin. (1991). Seluk Beluk Pendidikan dari Al-Ghazali. Jakarta: Bumi Aksara. 